\title{
Exchange Rate Flexibility and the Integration of the Securities Market in East Asia
}

\author{
Takuji Kinkyo and Shigeyuki Hamori
}

Faculty of Economics, Kobe University, 2-1, Rokkodai, Nada-ku, Kobe 657-8501, Japan

\begin{abstract}
This paper discusses the time-varying degree of flexibility in exchange rate regimes and assesses the extent to which securities markets are integrated in East Asia. The dynamic conditional correlation model developed by Engle (2002) is used to analyze the time-varying characteristics of the conditional correlations of exchange rates as well as of bond and equity returns in emerging Asian economies. First, the presented analyses find that the flexibility of Asia's exchange rate regimes increased substantially after the Asian crisis of 1997-98. Second, we show that Asia's equity markets are becoming more globally and regionally integrated, whereas the bond markets in the region are still divided by national borders. These results suggest the existence of more scope for policymakers to promote financial integration in Asia, particularly in its bond markets.
\end{abstract}

Keywords: Exchange rate flexibility, integration of the securities market, East Asia, dynamic conditional correlation.

\section{INTRODUCTION}

Economic integration in East Asia has been led by the rising trend of foreign trade and direct investment (FDI). Intra-regional FDI flows surged after the Plaza Accord of 1985, which resulted in the sharp appreciation of exchange rates in advanced Asian economies such as Japan, Korea, and Taiwan. The loss of export competitiveness due to appreciation encouraged manufacturing firms in those economies to relocate their labor-intensive production activities to Southeast Asia in order to exploit cost advantages. Since then, extensive production and distribution networks have been created across Asia and intraregional trade in intermediate goods has expanded rapidly. By contrast, economic integration through intraregional financial transactions, particularly portfolio investment, is lagging across Asia. For example, crossborder portfolio investment relative to GDP is much lower in Asia than it is in the euro area, while the proportion of intra-regional flows in total portfolio investment is also relatively small (Pongsaparn \& Unteroberdoerster, 2011).

Openness to capital flows and financial integration beyond national borders can increase the efficiency of the allocation of funds. For example, better access to foreign capital markets tends to provide opportunities for domestic firms and governments to raise funds at cheaper costs. Likewise, access to foreign markets allows domestic investors to diversify their portfolios and better manage risk.

*Address correspondence to this author at the Faculty of Economics, Kobe University, 2-1, Rokkodai, Nada-Ku, Kobe 657-8501, Japan; Tel: +81-78-8036832; E-mail: hamori@econ.kobe-u.ac.jp
Financial integration can also promote the development of domestic financial systems. First, opening alternative channels for financial intermediation exposes domestic financial institutions to competition, which encourages them to improve services and operational efficiency. Second, greater foreign participation in domestic capital markets leads to better price discovery and less price volatility not only by improving market liquidity but also by insisting on better corporate governance and greater degrees of transparency (Prasad \& Rajan, 2008). Finally, deep and liquid capital markets can serve as a buffer in the event of severe disruptions to bank financing channels (Felman et al., 2011).

Although financial openness can stimulate financial development, however, macroeconomic policymakers face one crucial dilemma. As the proposition of the Impossible Trinity suggests, fixed exchange rates and autonomous monetary policy cannot coexist under free capital movement (Frankel, 1999). In fact, developing countries are inclined to introduce relatively stringent controls on capital flows under fixed exchange rate systems in order to maintain a degree of autonomy over monetary policy. For instance, Asian economies have long maintained de facto dollar pegs, which have served as a nominal anchor for monetary policy and helped promote exports by mitigating foreign exchange risk. However, in response to the financial crisis of 1997-98, Asian economies abandoned dollar pegs and shifted toward exchange rate regimes such as managed floating rates that were characterized by greater flexibility, which allowed Asian economies to relax capital controls and promote financial integration without seriously undermining their ability to adopt proactive macroeconomic policies. 
Fostering more open and efficient financial systems will contribute to emerging economies' sustainable growth and thus reduce the risk of being stuck in 'middle-income trap'. It is therefore important for emerging Asian economies to facilitate cross-border financial integrations by getting policy priorities right. This study aims to provide some basis for identifying such policy priorities by evaluating the current state of exchange rate flexibility and cross-border securities market integration in East Asia. More specifically, the dynamic conditional correlation (DCC) model developed by Engle (2002) is used in this paper to analyze time-varying conditional correlations among exchange rates as well as of bond and equity returns in emerging Asian economies. Methodologically, we adopt a generalized autoregressive conditionally heteroskedastic (GARCH) model, which allows the volatility of a single variable to depend on past volatilities and means that conditional variance can thus vary over time. In the DCC model, therefore, which is a multivariate extension of GARCH-family models, the volatility of multiple variables depends on each other and the conditional correlations among these variables can then vary over time.

Because the shift in exchange rate regimes and the integration of the securities market tend to be gradual and ongoing processes, estimating the DCC model has an advantage over simple correlation analysis. While simple static correlation analysis provides little information on the dynamics of correlations, the DCC model indicates when and how correlations change and the extent to which they remain stable over time. Understanding the dynamics of correlations is crucial for examining the time-varying characteristics of exchange rate regimes and integration of the securities market ${ }^{1}$. Indeed, the DCC model has been applied across a wide range of research areas including the studies by Yang (2005), Savva, Osborn, and Gill (2008), Toyoshima, Tamakoshi, and Hamori (2012), Kinkyo (2012), Tamakoshi and Hamori (2013), Toyoshima, Nakajima, and Hamori (2013) and Toyoshima and Hamori (2013).

The rest of the paper is organized as follows. Sections 2 and 3 provide the estimation results of the conditional correlations of exchange rates and of bond

\footnotetext{
${ }^{1}$ It should also be noted that a major economic event, such as a financial crisis could be the trigger for the change in the correlations of asset prices. For example, Xu and Hamori (2012) find that the dynamic linkages between the BRIC countries and the United States in the mean and variance of stock prices weakened after the 2008-09 US financial crisis.
}

and equity returns, respectively. Section 4 briefly discusses the potential barriers to cross-border investment. Section 5 concludes.

\section{FLEXIBILITY IN EXCHANGE RATE REGIMES}

The Asian financial crisis of 1997-98 highlighted the vulnerability of pegged-but-adjustable exchange rate regimes to speculative attacks and sudden capital flow reversals. It also demonstrated how a disorderly exit from pegged exchange rate regimes could result in economic disaster. In response to the crisis, Asian economies thus abandoned de facto dollar pegs and adopted exchange rate regimes characterized by greater flexibility. However, as noted in the Introduction, fixed exchange rates and an autonomous monetary policy cannot coexist under free capital movement. The greater exchange rate flexibility of Asian economies thus creates more room for proactive policies that safeguard against external shocks even in an environment of freer capital mobility. In fact, Asian economies successfully counteracted the adverse impact of the global financial crisis of 2007-09 by adopting fiscal and monetary stimulus measures. These policies in the wake of the recent financial crisis contrast sharply with the policy responses to the Asian crisis, when Indonesia, Korea, and Thailand initially tightened their fiscal and monetary policies in an attempt to stabilize capital flows and exchange rates in line with IMF programs. Critics of the IMF program argue that its contractionary policies further weakened domestic demand, exacerbating the economic downturn (Furman \& Stiglitz, 1998).

To examine the degree of flexibility in Asia's exchange rate regimes, the conditional correlations of exchange rates are estimated by using the DCC model estimated for weekly changes in the values of nine currencies, namely six Asian currencies (the Chinese renminbi, Indonesian rupiah, Korean won, Malaysian ringgit, Philippine peso, and Thai baht) and three major currencies (the US dollar, Japanese yen, and euro). These currency values are measured by using the Swiss franc as a numeraire and expressed in logarithm terms. The sample period runs from the first week of February 1994to the last week of December $2012^{2}$.

The conditional correlations between these Asian currencies and the major currencies are plotted in

\footnotetext{
${ }^{2}$ The period starts in February 1994 in order to rule out the effect of the major change in the Chinese exchange rate regime in January 1994, during which dual exchange rates were unified and the official rate was devalued by a large degree.
} 
(a) Chinese Renminbi

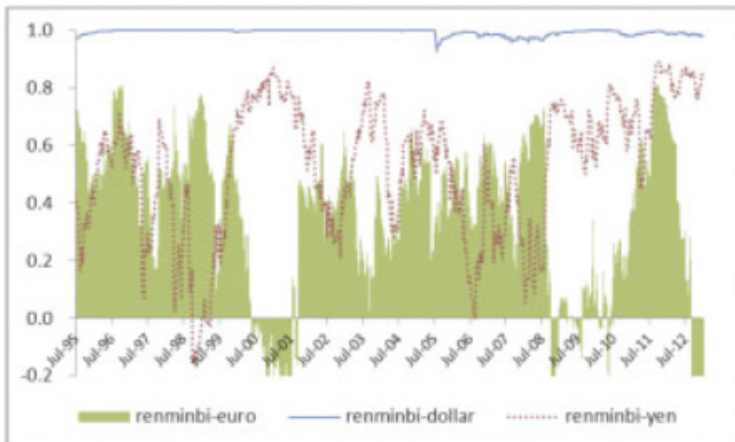

(c) Korean Won

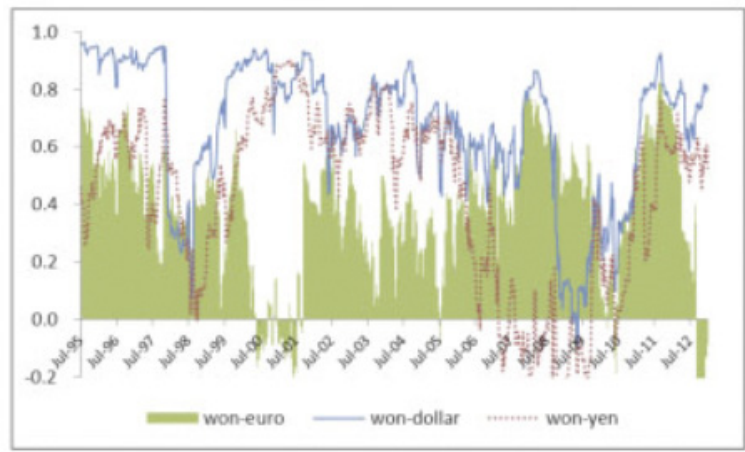

(e) Philippine Peso

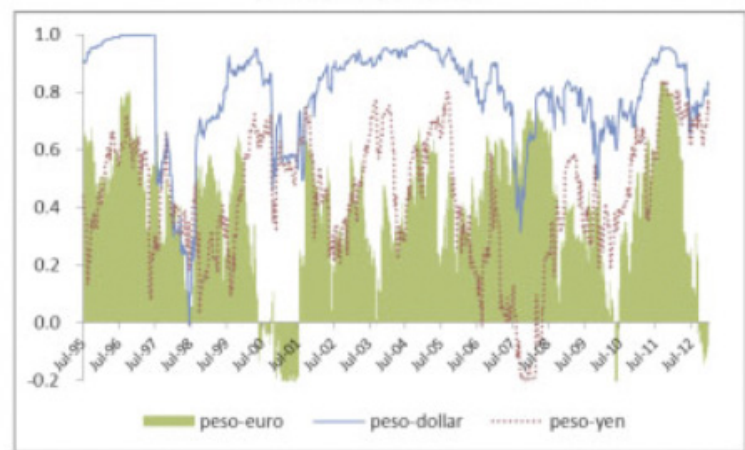

(b) Indonesian Rupiah

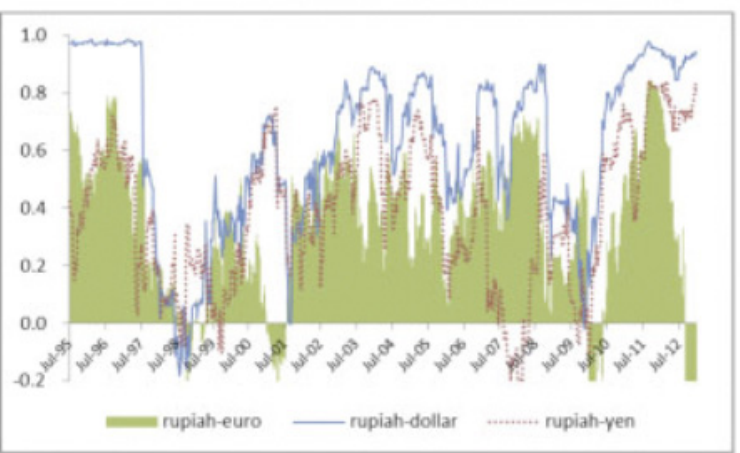

(d) Malaysian Ringgit



(f) Thai baht

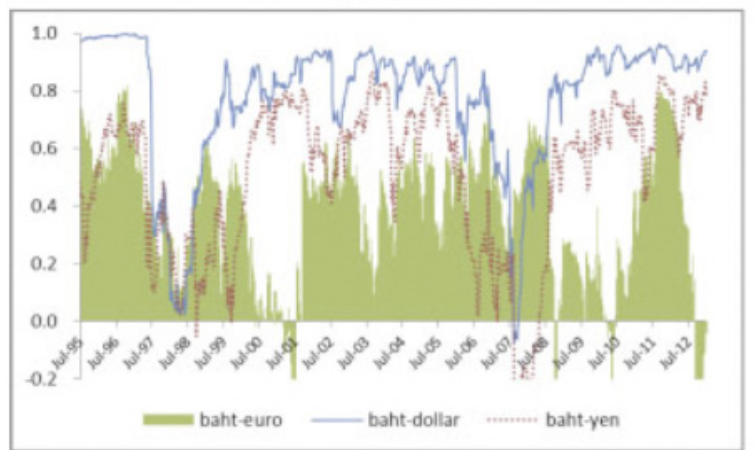

Figure 1: Conditional Correlations between the Asian and Major Currencies.

Figure $\mathbf{1}^{3}$. This figure illustrates that all Asian currencies closely correlated with the dollar before the Asian crisis, notably the renminbi and the baht. In 1996, the annual average correlation of the renminbi and the baht with the dollar was as high as 0.99 , while standard deviations were below 0.01 . Indeed, the wondollar correlation was relatively more volatile, although its annual average correlation still exceeded 0.9. By comparison, the correlations of the Asian currencies with the yen and the euro were much weaker (approximately $60-70 \%$ of the correlation with the

${ }^{3}$ The DCC model is estimated based on the assumption that the weekly change in currency values follows the Student's $t$-distribution. The estimated parameters of the DCC model are all statistically significant at conventional significance levels. dollar) and standard deviations were substantially larger. These results are consistent with the common understanding that these Asian currencies were effectively pegged to the dollar before the crisis.

During the Asian financial crisis, the correlations between the five crisis-hit Asian currencies (i.e., the studied currencies except the renminbi) and all three major currencies declined, whereas that between the renminbi and the dollar remained as strong as before because China's dollar peg survived the Asian crisis. Moreover, although the correlations between the crisishit Asian currencies and the dollar rose again after the Asian crisis, they were weaker and much more volatile than before, while correlational differences with the dollar and the yen also narrowed. One exception was 
the ringgit, which became even more closely correlated with its pegged currency the dollar given that the Malaysian authorities had responded to the crisis by imposing capital controls in September 1998. However, the ringgit-dollar correlation declined sharply following the shift to managed floating rates in July 2005.

The peso and the baht maintained relatively close correlations with the dollar compared with the yen after the Asian crisis, particularly the former. However, these currencies' correlations with the dollar were much more volatile than before the Asian crisis. Similarly, the renminbi continued to be strongly correlated with the dollar after the crisis. The renminbi-dollar correlation consistently remained above 0.99 until a new exchange rate regime was introduced in July 2005 under which the renminbi was managed with reference to a basket of currencies rather than being pegged to the dollar. However, although the renminbi-dollar correlation declined immediately after the introduction of this new regime, it returned to levels above 0.98 by the end of the year.

During the global financial crisis of 2007-09, the correlations of Asian currencies with the dollar, except for the renminbi, declined rapidly because of the acceleration of deleveraging by international financial institutions, which drove down exchange rates in emerging market economies, including those in Asia. Among the Asian currencies examined herein, the won and the rupiah were hit hardest, whereas, again, the renminbi continued to be strongly correlated with the dollar. Although their correlation became slightly more volatile, the annual average was approximately 0.99 and the standard deviation remained below 0.01 from 2009 through 2012.

To summarize, the above results indicate that the degree of flexibility in Asia's exchange rate regimes has increased substantially since the exit from dollar pegs in the wake of the crisis. Post-crisis exchange rate regimes can be best characterized as managed floating rates that have varying degrees of flexibility. In sharp contrast, there seems to have been little fundamental change to China's exchange rate regime throughout the sample period. The strong correlation between the renminbi and the dollar indicates that the former continued to be managed very tightly with reference to the latter. The greater flexibility in exchange rate regimes has allowed crisis-hit Asian economies to promote financial integration without seriously undermining their ability to adopt proactive macroeconomic policies. The enhanced capability of counteracting adverse shocks has also helped stabilize market expectations, preventing panic-driven capital outflows in the face of financial contagion.

\section{INTEGRATION OF THE SECURITIES MARKET}

As noted in the Introduction, while economic integration in East Asia has been led by FDI, economic integration through intra-regional financial transactions, particularly portfolio investment, is lagging in this region. In this section, the DCC model is used to estimate the conditional correlations between bond and equity returns in emerging East Asian economies in order to assess the degree to which Asia's securities markets are integrated through cross-border investment and arbitrage. Greater market integration will strengthen the correlation of bond and equity returns across the markets.

The DCC model is estimated for the weekly local government bond returns and equity returns in nine emerging Asian economies and global markets. Local bond returns are measured by using the weekly log difference of the HSBC Asian Local Bond Index (ALBI). The HSBC ALBI tracks the total return performance of a portfolio that consists of local currency-denominated, high-quality, and liquid government bonds in Asia, excluding Japan ${ }^{4}$. Global bond market returns are measured by using the weekly log difference of the Citigroup World Government Bond Index (WGBI). The WGBI includes the government bond markets of 23 major economies and the index is denominated in the dollar. Local equity returns are measured by using the weekly log difference of the benchmark equity price index. Global equity market returns are measured by the weekly log difference of the Morgan Stanley Capital International (MSCl) World Index. The MSCl World Index includes the equity markets of 24 major economies and it is denominated in the dollar. The nine Asian economies include ASEAN5 (Indonesia: IN, Malaysia: MY, the Philippines: PH, Singapore: SG, Thailand: $\mathrm{TH}$ ) and four Northeast Asian economies (China: CN, Hong Kong: HK, Taiwan: TW, Korea: KR). The sample period runs from the first week of January 2001 to the last week of December 2012. Data sources are Bloomberg and CEIC Data. Since the variation of exchange rates could affect the correlation of bond and

\footnotetext{
${ }^{4}$ The selection criteria of the ALBI includes the following: (i)Currency: Respective domestic currencies; (ii) Coupon type: Fixed rate only, (iii) Bond type; Government, quasi-government and corporate bonds; (iv) Credit ratings; Restriction based on individual country; (v) Issue size; Minimum issue size is required and it varies across country; and (vi) Maturity; Minimum of one year remaining to maturity (HSBC, 2012).
} 
(a) ASEAN (local currency-denominated returns)



(c) Northeast Asia (local currency-denominated returns)

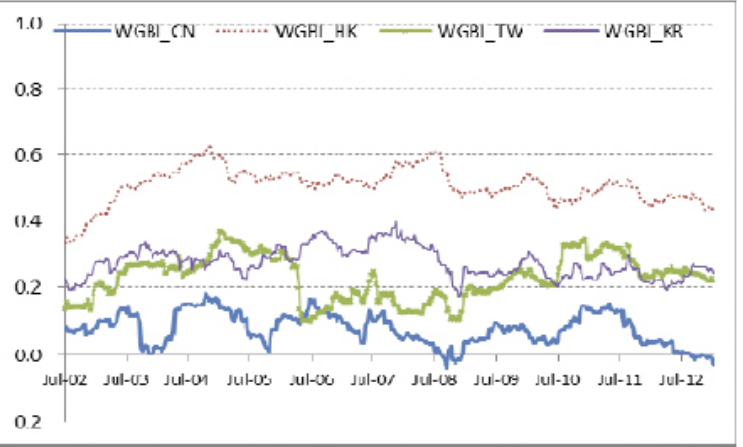

(b) ASEAN (dollar-denominated returns)

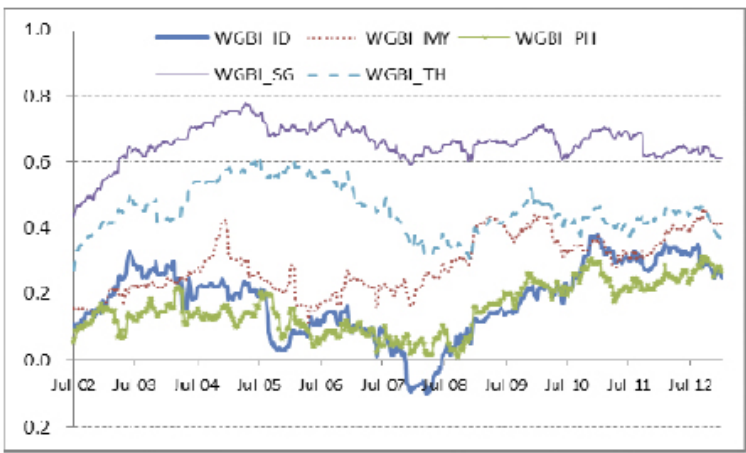

(d) Northeast Asia (dollar-denominated returns)

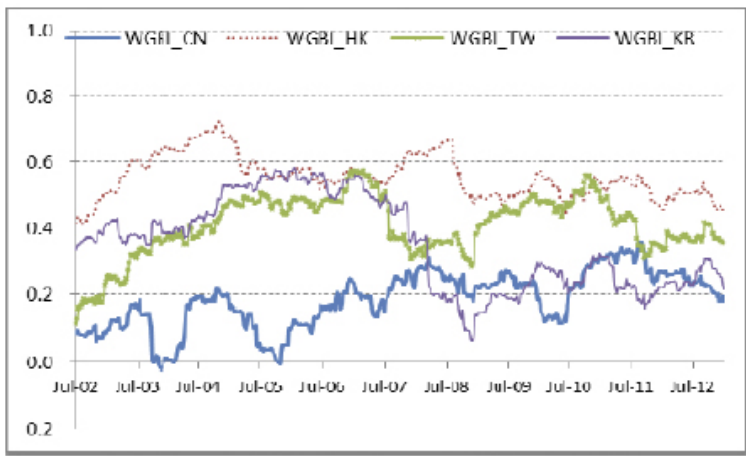

Figure 2: Conditional Correlations of Bond Returns (vis-à-vis the WGBI).

equity returns, we estimate the DCC model both for the local-currency and the US dollar denominated returns. The local-currency denominated returns are converted into the dollar denominated returns using the market exchange rates ${ }^{5}$.

\subsection{Bond Markets}

The estimated conditional correlations of bond returns between the local markets in studied economies and the global market are plotted in Figure $2^{6}$. In all economies, we see that the correlations of bond returns are generally higher in dollar terms than they are in local currency terms. This result indicates that exchange rate variations significantly affect the correlation of bond returns in Asian markets. The correlation of local returns with global returns is particularly high in Singapore and Hong Kong, reflecting two factors. First, the degree of integration with the global financial market is high in Hong Kong and Singapore because these domestic capital markets

\footnotetext{
${ }^{5}$ Fung, Tam, and Yu (2008) estimate the conditional correlations of bond and equity returns converted into dollars. However, the effect of exchange rate variations is not examined by comparing the results between local currencydenominated and dollar-denominated returns.

${ }^{6}$ The DCC model is estimated based on the assumption that bond and equity returns follow the Student's $t$-distribution. The estimated parameters of the DCC model are all statistically significant at conventional significance levels.
}

are relatively more open and developed. Second, the currencies of Hong Kong and Singapore are either pegged to the dollar or managed with reference to a basket of currencies that includes the dollar as a key component. Under this dollar peg or quasi-dollar peg, these economies effectively import US monetary policy. In other words, it is likely that the close correlation with global returns reflects the close correlation with US returns.

In other economies, the correlations of bond returns between the local and the global markets are relatively weak. Although the correlations of dollar-denominated returns are relatively high in Thailand and Taiwan, they remain below 0.5 for most of the sample period. In Korea, the correlation of dollar-denominated returns declined and remained low after the global financial crisis. Further, the correlation with global returns is particularly weak in Indonesia, the Philippines, and China both in dollar and in local currency terms.

The estimated conditional correlations of bond returns within the ASEAN region are plotted in Figure 3. In this region, there is a noticeable increase in the correlations of bond returns, particularly dollardenominated returns. In addition, there is a tendency for the level of correlations to converge among ASEAN economies. 


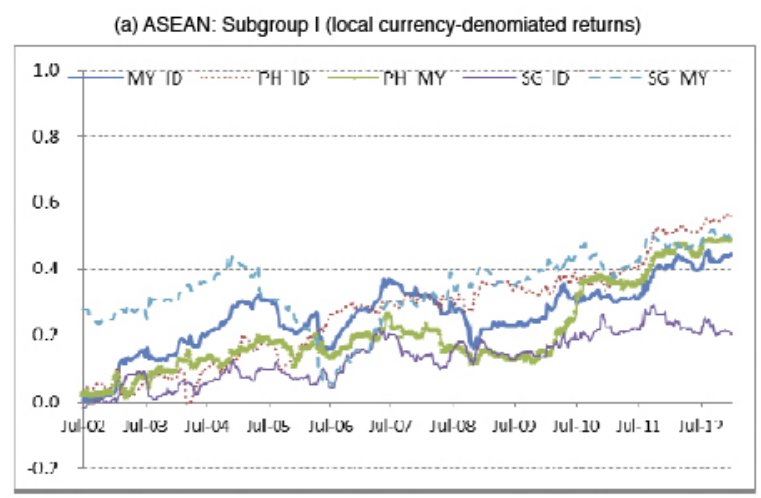

(c) ASEAN: Subgroup II (local currency-denomiated returns)

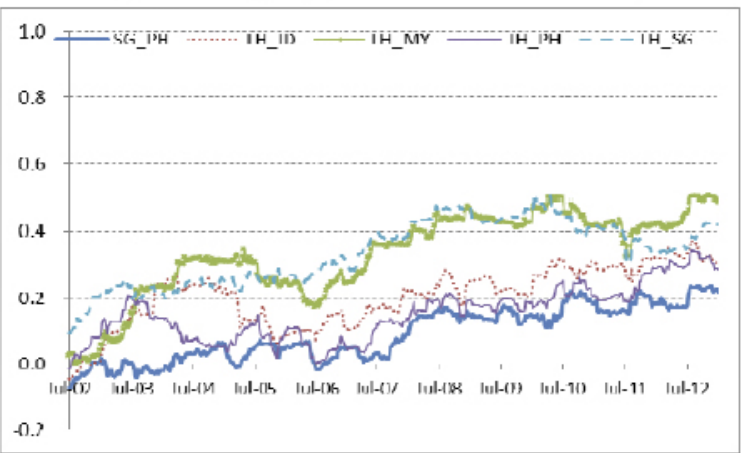

(b) ASEAN: Subgroup I (dollar-denominated returns)

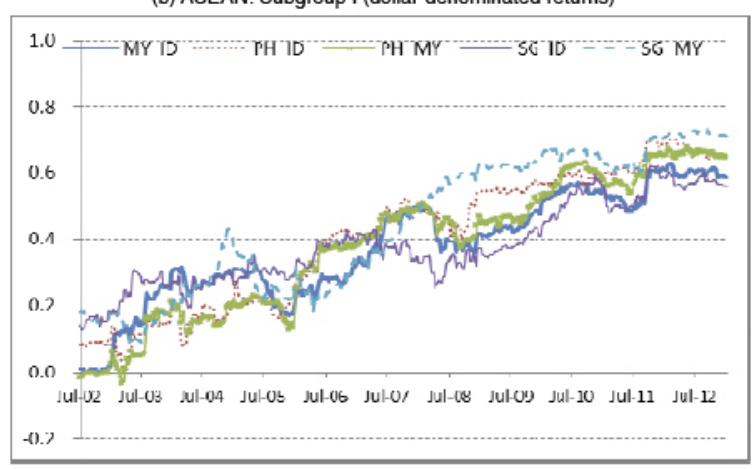

(d) ASEAN: Subgroup II (dollar-denominated returns)



Figure 3: Conditional Correlations of Bond Returns (Intra-ASEAN).

The estimated conditional correlations of bond returns among Northeast Asian economies are plotted in Figure 4. By comparison, the correlations of bond returns among these economies are weak in both dollar and local currency terms. Indeed, all pairs of correlations of bond returns remain below 0.5 throughout the sample period, except for the correlation of dollar-denominated returns between Korea and Taiwan.

The estimated conditional correlations of bond returns between ASEAN and Northeast Asian economies are plotted in Figure 5. The correlation of dollar-denominated returns with Hong Kong and Taiwan has recently reached relatively high levels in

(a) Local currency-denominated returns

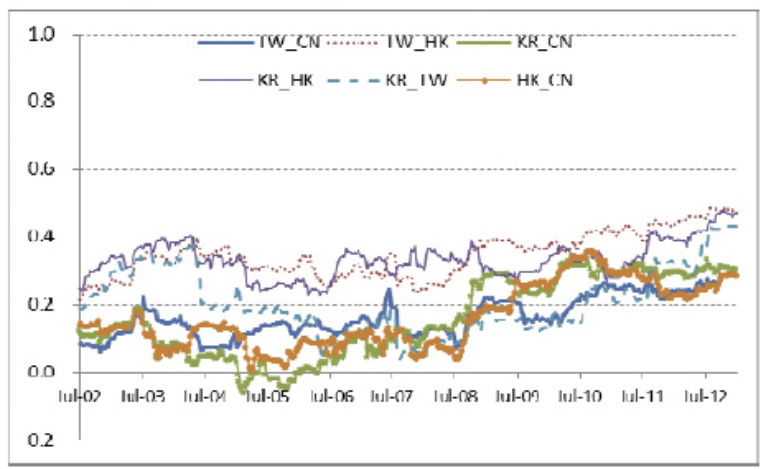

Malaysia, the Philippines, and Singapore. By contrast, the correlations of bond returns between ASEAN economies and China remained low in both dollar and local currency terms throughout the sample period. There is also no clear upward trend in the correlations between ASEAN economies and Hong Kong except for a steady increase in the correlation of local currencydenominated returns between Singapore and Hong Kong.

\subsection{Equity Markets}

The estimated conditional correlations of equity returns between local markets and the global market

(b)Dollar-denominated returns



Figure 4: Conditional Correlations of Bond Returns (Intra-Northeast Asia). 
(a) ASEAN-China (local currency-denominated returns)

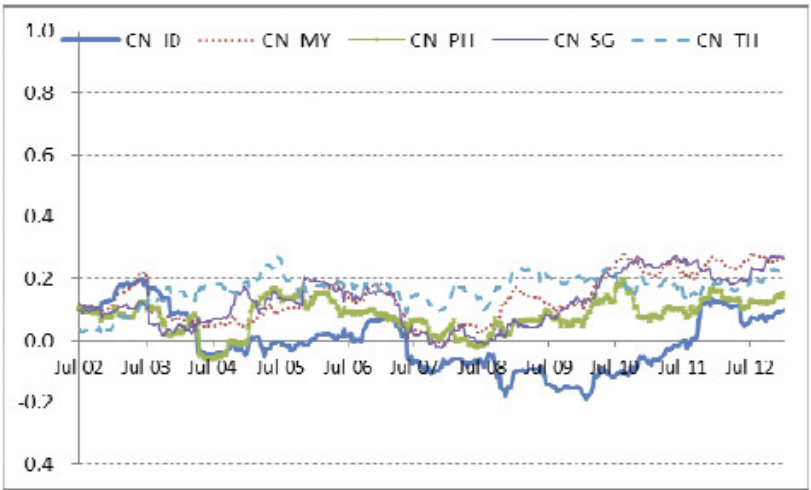

(c) ASEAN-Hong Kong (local currency-denominated returns)

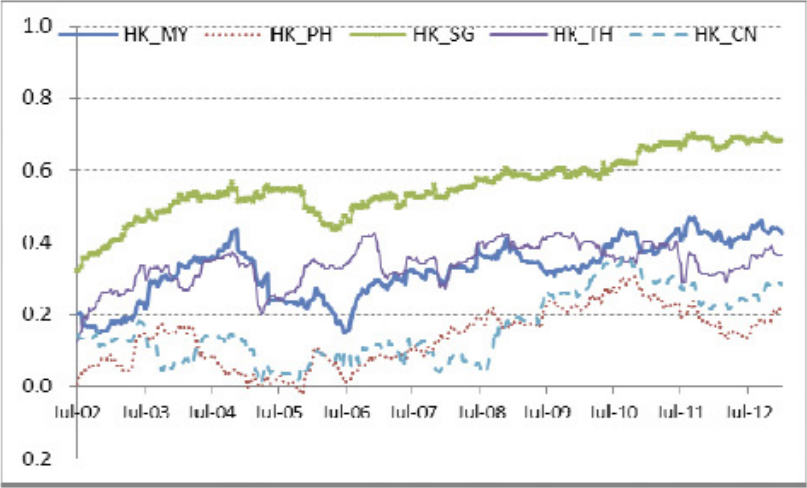

(e) ASEAN-Taiwan (local currency-denominated returns)

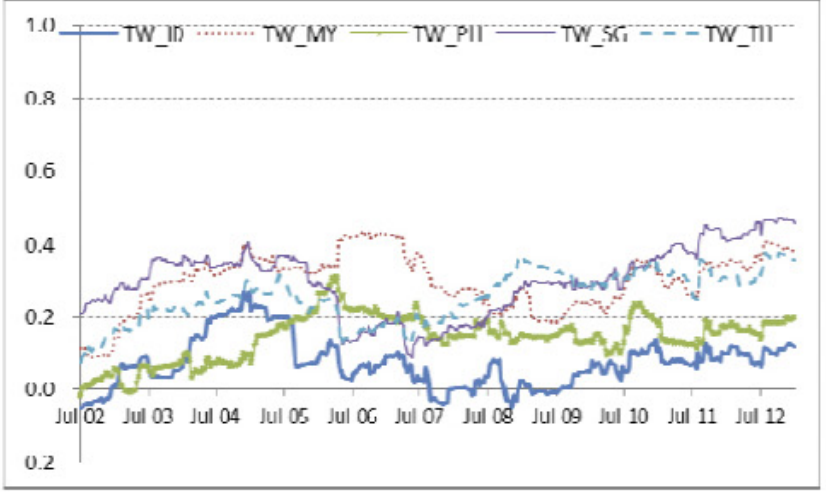

(g) ASEAN-Korea (local currency-denominated returns)

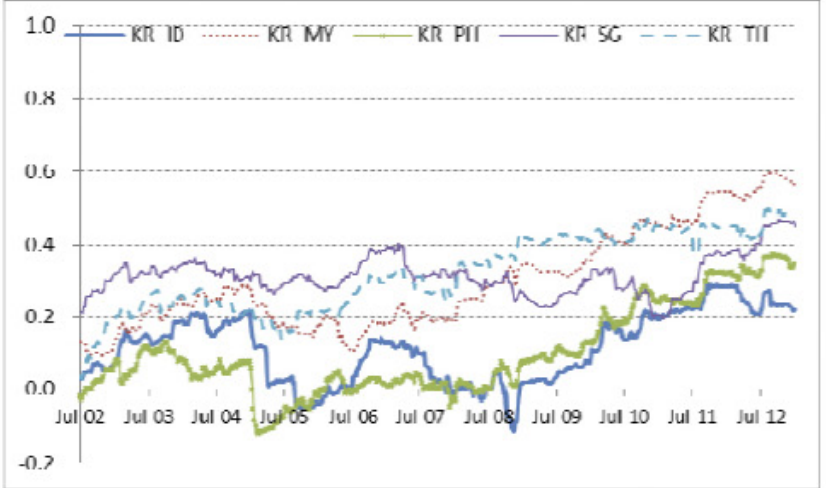

(b) ASEAN-China (dollar-denominated returns)

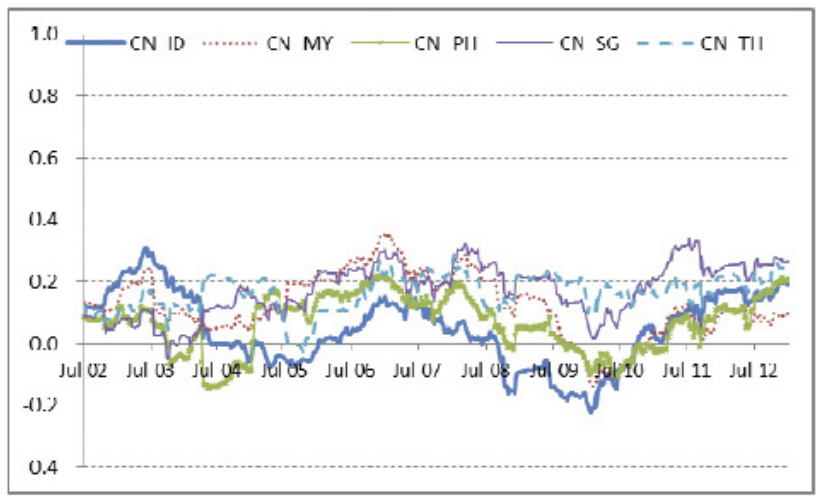

(d) ASEAN-Hong Kong (dollar-denominated returns)



(f) ASEAN-Taiwan (dollar-denominated returns)

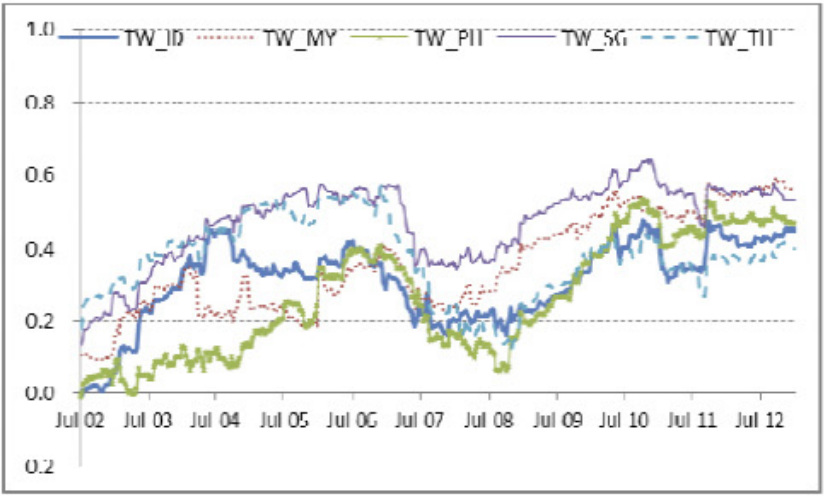

(h) ASEAN-Korea (dollar-denominated returns)

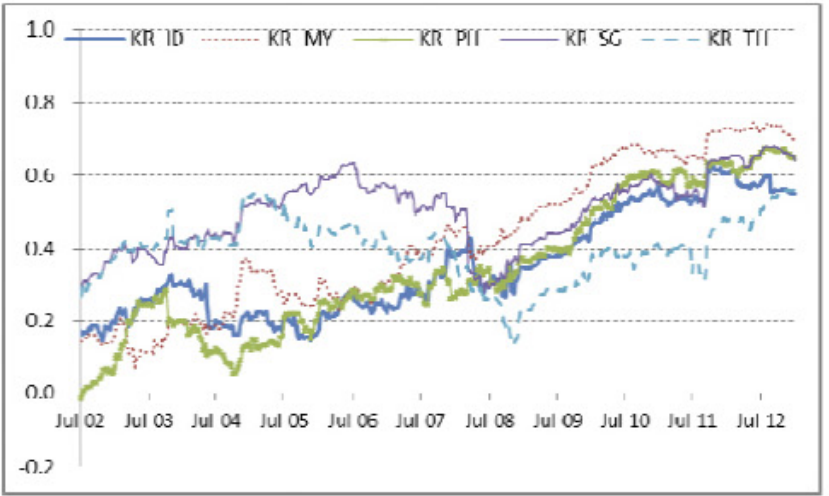

Figure 5: Conditional Correlations of Bond Returns (ASEAN vis-à-vis Northeast Asia). 
(a) ASEAN (local currency-denominated returns)

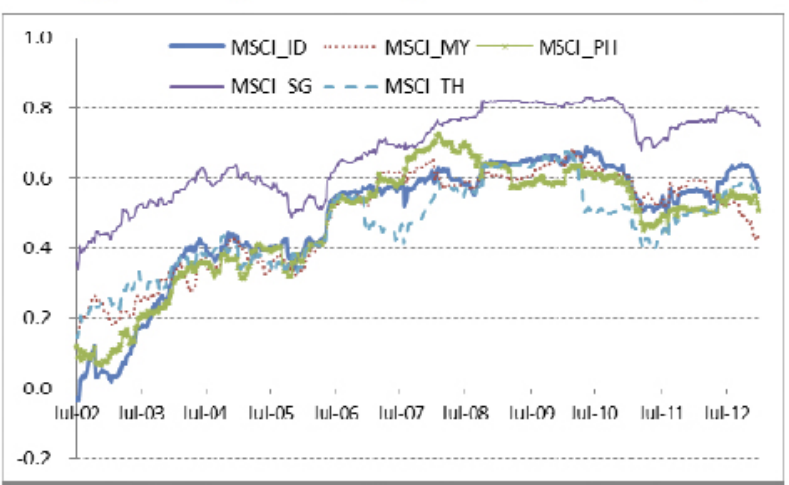

(c) Northeast Asia (local currency-denominated returns)

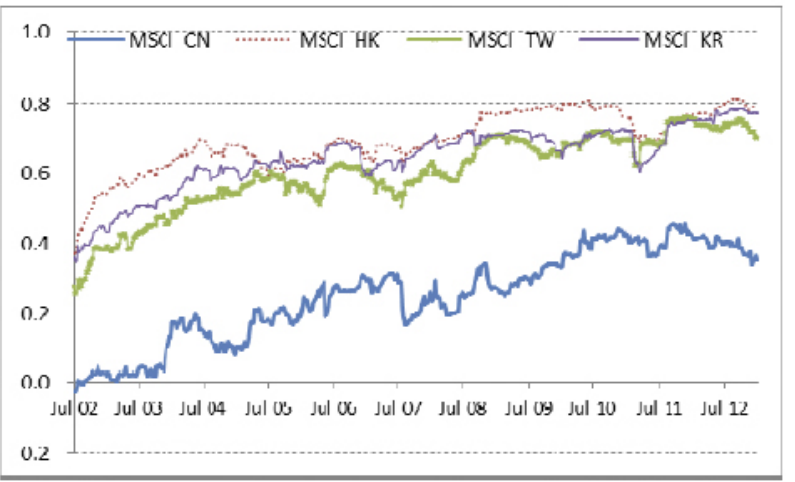

(b) ASEAN (dollar-denominated returns)

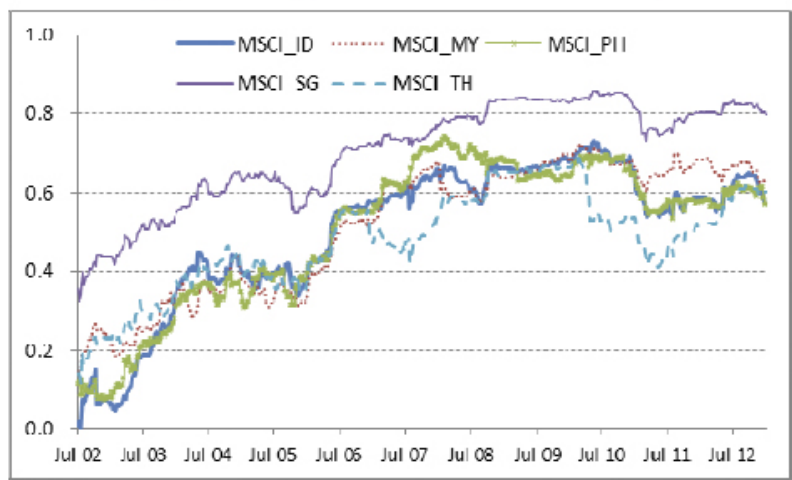

(d) Northeast Asia (dollar-denominated returns)



Figure 6: Conditional Correlations of Equity Returns (vis-à-vis MSCI).

are plotted in Figure $6^{7}$. This figure shows that there is relatively a small difference in the correlations of equity returns between local currency- and dollardenominated returns. The same can be said about the intra-Asian correlations of equity returns as shown below. These result simply that the absolute size of equity returns tends to be greater than that of exchange rate variation. The correlation of local market returns with global market returns is very high in Singapore, Hong Kong, Taiwan, and Korea. The correlation with global returns has increased and reached relatively high levels in Indonesia, Malaysia, the Philippines, and Thailand. However, although the correlation with global returns has risen in China, it remains much lower than that in other Asian economies.

The estimated conditional correlations of equity returns within ASEAN economies are plotted in Figure 7. The correlations of equity returns continued to increase within the ASEAN region throughout the 2000s and reached high levels in the recent period. In

\footnotetext{
${ }^{7}$ The DCC model is estimated based on the assumption that equity returns follow the Student's $t$-distribution. The estimated parameters of the DCC model are statistically significant at conventional significance levels.
}

addition, we see a tendency for the level of correlations to converge among ASEAN economies.

The estimated conditional correlations of equity returns among Northeast Asian economies are plotted in Figure 8. These correlations have increased and reached high levels among Hong Kong, Taiwan, and Korea, but remained low between these economies and China.

The estimated conditional correlations of equity returns between ASEAN and Northeast Asian economies are plotted in Figure 9. In all ASEAN economies, there has been an increase in the correlations with Hong Kong, Taiwan, and Korea. An upward trend can also be observed in the correlation between ASEAN economies and China. However, the levels of these correlations remain below 0.5 throughout the sample period.

To highlight the difference between Asia's bond and equity markets in terms of the progress of market integration, the average estimated conditional correlations are computed for the following sub-periods of the sample: the period prior to the global financial crisis (first week of 2004 to the last week of 2006), the period during the global financial crisis (first week of 
(a) ASEAN: Subgroup I: (local currency-denominated returns)

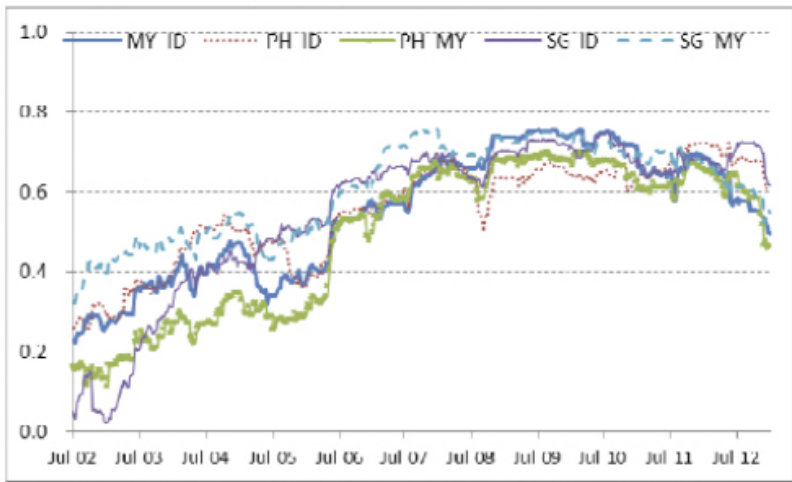

(c) ASEAN: Subgroup II (local currency-denominated returns)

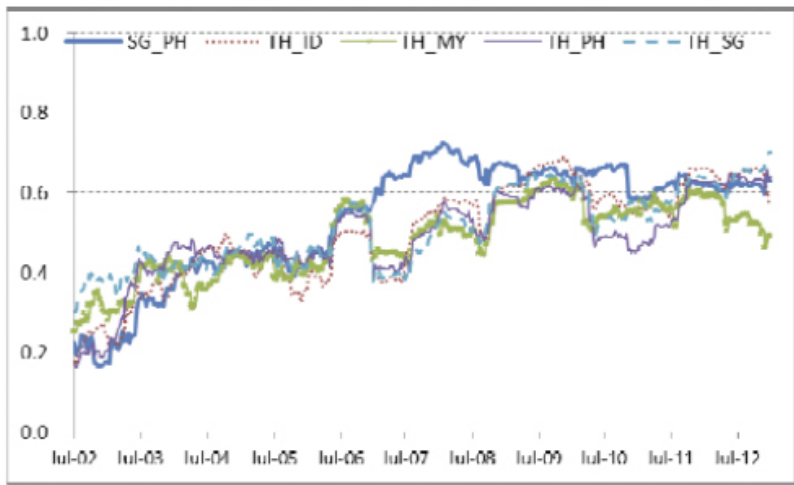

(b) ASEAN: subgroup I (dollar-denominated returns)



(d) ASEAN: subgroup II (dollar-denominated returns)

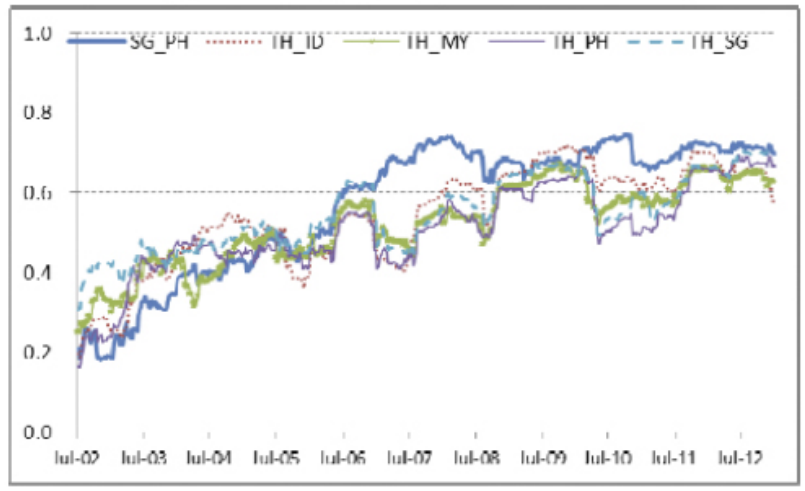

Figure 7: Conditional Correlations of Equity Returns (Intra- ASEAN).

(a) Local currency-denominated returns

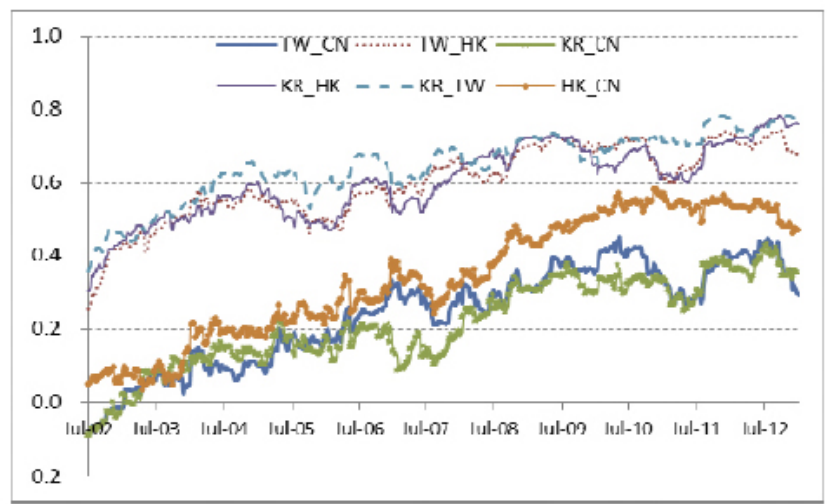

(b) Dollar-denominated returns

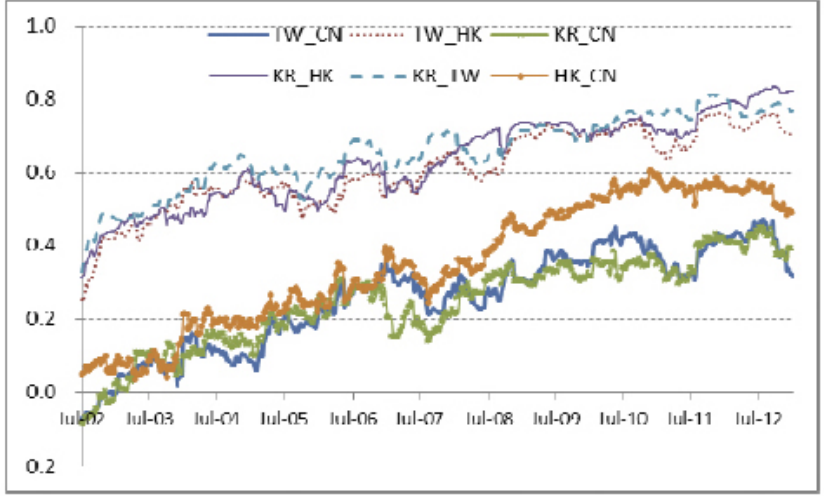

Figure 8: Conditional Correlations of Equity Returns (Intra-Northeast Asia).

2007 to the last week of 2009), and the post-crisis period (first week of 2010 to the last week of 2012). We treat the crisis period separately because the correlation of asset returns could increase temporarily at times of market turbulence due to investors' herd behavior. Table 1 shows the average correlations both in local currency-and dollar-denominated returns. The correlations of returns are generally higher inequity markets than they are in bond markets. In addition, the correlations of equity returns continued to increase through the three sub-periods. The results clearly show that equity markets are integrated more globally and regionally than bond markets in Asia.

To summarize, the above results indicate that Asia's equity markets are increasingly integrated both regionally and with the global market. Although the present analysis provides insufficient evidence to determine whether the observed convergence is caused directly by intra-regional integration or indirectly by the global integration of equity markets, it is conceivable that both factors have contributed to this 
(a) ASEAN-China (local currency-denominated returns)



(c) ASEAN-Hong Kong (local currency-denominated returns)



(e) ASEAN-Taiwan (local currency-denominated returns)

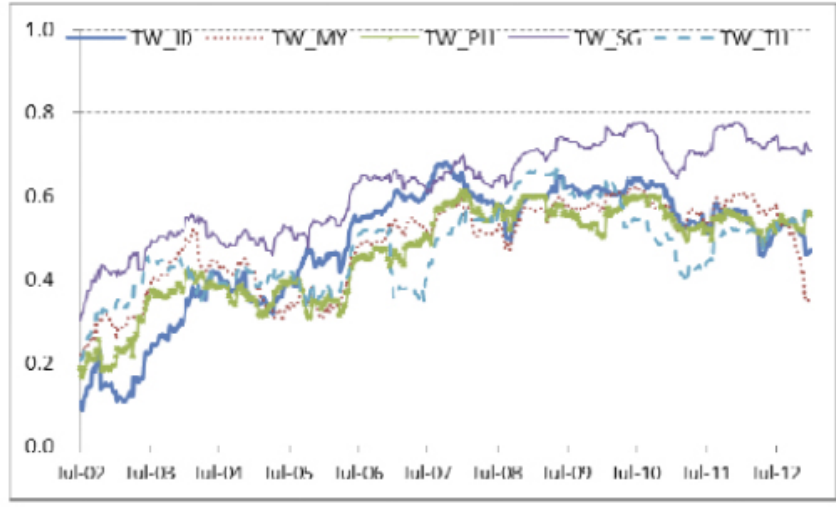

(g) ASEAN-Korea (local currency-denominated returns)



(b) ASEAN-China (dollar-denominated returns)

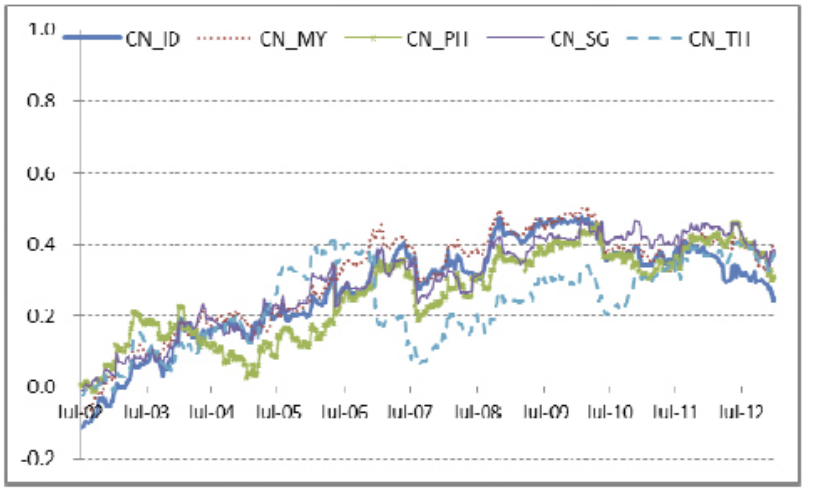

(d) ASEAN-Hong Kong (dollar-denominated returns)

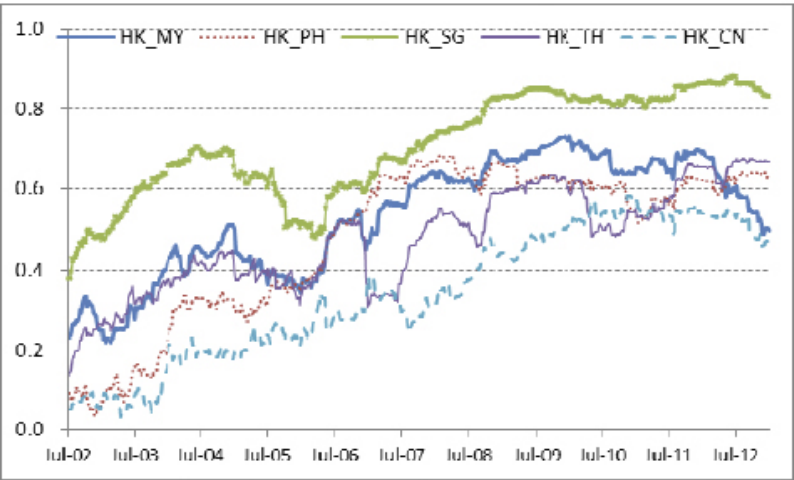

(f) ASEAN-Taiwan (dollar-denominated returns)

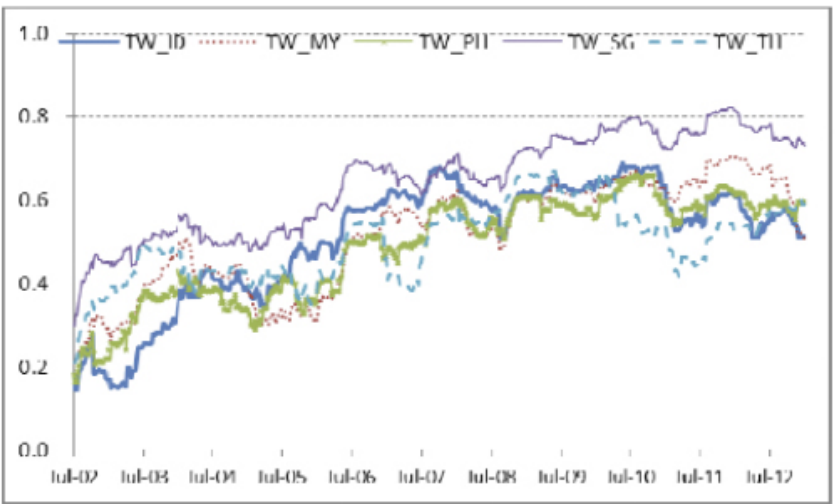

(h) ASEAN-Korea (dollar-denominated returns)

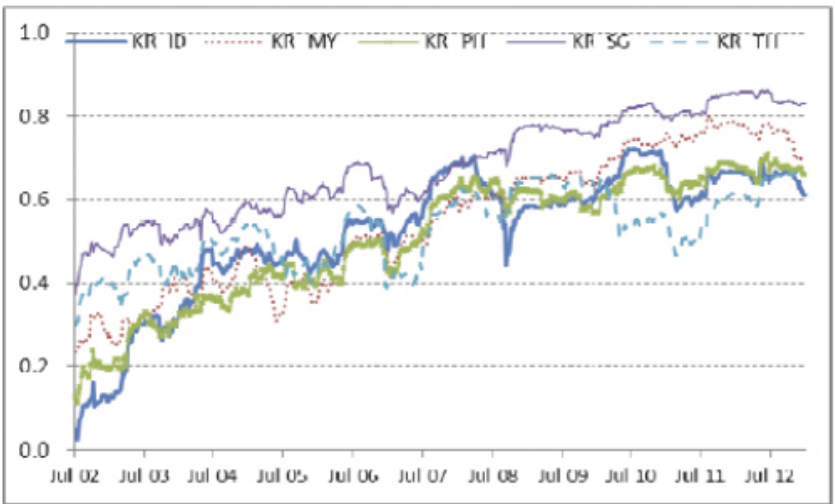

Figure 9: Conditional Correlations of Equity Returns (ASEAN vis-à-vis Northeast Asia). 
Table 1a: Average Conditional Correlations (Local Currency-Denominated Returns)

\begin{tabular}{|c|c|c|c|c|c|c|c|}
\hline & \multicolumn{3}{|c|}{ Bond Markets } & & \multicolumn{3}{|c|}{ Equity Markets } \\
\hline MY_ID & 0.23 & 0.27 & 0.36 & MY_ID & 0.43 & 0.67 & 0.66 \\
\hline PH_MY & 0.15 & 0.17 & 0.38 & PH_MY & 0.34 & 0.64 & 0.63 \\
\hline SG_ID & 0.08 & 0.15 & 0.22 & SG_ID & 0.49 & 0.68 & 0.69 \\
\hline SG_PH & 0.03 & 0.11 & 0.18 & SG_PH & 0.46 & 0.66 & 0.63 \\
\hline TH_ID & 0.17 & 0.21 & 0.30 & TH_ID & 0.44 & 0.56 & 0.61 \\
\hline TH_MY & 0.27 & 0.39 & 0.44 & TH_MY & 0.44 & 0.53 & 0.56 \\
\hline TH_PH & 0.07 & 0.15 & 0.25 & TH_PH & 0.47 & 0.53 & 0.56 \\
\hline TH_SG & 0.26 & 0.42 & 0.40 & TH_SG & 0.46 & 0.53 & 0.60 \\
\hline $\mathrm{KR} \_\mathrm{CN}$ & 0.02 & 0.17 & 0.30 & KR_CN & 0.15 & 0.24 & 0.34 \\
\hline KR_HK & 0.30 & 0.32 & 0.37 & KR_HK & 0.55 & 0.65 & 0.69 \\
\hline KR_TW & 0.19 & 0.12 & 0.28 & KR_TW & 0.62 & 0.68 & 0.73 \\
\hline CN_ID & 0.00 & -0.08 & 0.00 & CN_ID & 0.19 & 0.38 & 0.34 \\
\hline CN_MY & 0.10 & 0.09 & 0.24 & CN_MY & 0.23 & 0.38 & 0.37 \\
\hline $\mathrm{CN}$ _PH & 0.08 & 0.04 & 0.12 & $\mathrm{CN} \_\mathrm{PH}$ & 0.14 & 0.30 & 0.33 \\
\hline CN_SG & 0.13 & 0.05 & 0.22 & CN_SG & 0.15 & 0.32 & 0.40 \\
\hline CN_TH & 0.18 & 0.17 & 0.19 & CN_TH & 0.22 & 0.15 & 0.29 \\
\hline HK_ID & 0.08 & 0.03 & 0.06 & HK_ID & 0.44 & 0.67 & 0.64 \\
\hline TW_PH & 0.16 & 0.16 & 0.16 & TW_PH & 0.38 & 0.55 & 0.55 \\
\hline TW_SG & 0.29 & 0.22 & 0.39 & TW_SG & 0.54 & 0.67 & 0.73 \\
\hline TW_TH & 0.23 & 0.26 & 0.32 & TW_TH & 0.42 & 0.55 & 0.51 \\
\hline KR_ID & 0.09 & 0.04 & 0.22 & KR_ID & 0.44 & 0.58 & 0.61 \\
\hline KR_MY & 0.21 & 0.27 & 0.49 & KR_MY & 0.40 & 0.54 & 0.61 \\
\hline KR_PH & 0.00 & 0.04 & 0.27 & KR_PH & 0.41 & 0.55 & 0.56 \\
\hline KR_SG & 0.32 & 0.30 & 0.34 & KR_SG & 0.57 & 0.67 & 0.74 \\
\hline KR_TH & 0.23 & 0.36 & 0.44 & KR_TH & 0.45 & 0.58 & 0.55 \\
\hline WGBI_ID & 0.08 & 0.04 & 0.20 & MSCI_ID & 0.43 & 0.61 & 0.59 \\
\hline WGBI_MY & 0.28 & 0.23 & 0.28 & MSCI_MY & 0.40 & 0.61 & 0.57 \\
\hline WGBI_PH & 0.09 & 0.09 & 0.17 & MSCl_PH & 0.40 & 0.63 & 0.55 \\
\hline WGBI_SG & 0.40 & 0.39 & 0.40 & MSCI_SG & 0.59 & 0.76 & 0.77 \\
\hline WGBI_TH & 0.25 & 0.27 & 0.25 & MSCl_TH & 0.41 & 0.57 & 0.52 \\
\hline WGBI_CN & 0.11 & 0.06 & 0.06 & MSCl_CN & 0.19 & 0.27 & 0.40 \\
\hline WGBI_HK & 0.55 & 0.53 & 0.48 & MSCl_HK & 0.66 & 0.73 & 0.77 \\
\hline WGBI_TW & 0.26 & 0.18 & 0.27 & MSCl_TW & 0.56 & 0.63 & 0.71 \\
\hline WGBI_KR & 0.30 & 0.29 & 0.24 & MSCI_KR & 0.62 & 0.68 & 0.72 \\
\hline
\end{tabular}

Note: IN; Indonesia, MY; Malaysia, PH; the Philippines, SG; Singapore, TH; Thailand, CN; China, HK; Hong Kong, TW; Taiwan, KR; Korea; WGBI; Citigroup World Government Bond Index, MSCl; Morgan Stanley Capital International World Index. 
Table 1b: Average Conditional Correlations (Dollar-Denominated Returns)

\begin{tabular}{|c|c|c|c|c|c|c|c|}
\hline & \multicolumn{3}{|c|}{ Bond Markets } & & \multicolumn{3}{|c|}{ Equity Markets } \\
\hline MY_ID & 0.27 & 0.42 & 0.56 & MY_ID & 0.45 & 0.70 & 0.74 \\
\hline PH_ID & 0.25 & 0.49 & 0.63 & PH_ID & 0.49 & 0.66 & 0.72 \\
\hline PH_MY & 0.23 & 0.45 & 0.61 & PH_MY & 0.35 & 0.67 & 0.71 \\
\hline SG_ID & 0.31 & 0.36 & 0.54 & SG_ID & 0.53 & 0.72 & 0.74 \\
\hline SG_PH & 0.20 & 0.33 & 0.54 & SG_PH & 0.48 & 0.69 & 0.71 \\
\hline TH_ID & 0.35 & 0.33 & 0.49 & TH_ID & 0.49 & 0.59 & 0.65 \\
\hline TH_MY & 0.31 & 0.43 & 0.50 & TH_MY & 0.46 & 0.56 & 0.61 \\
\hline TH_PH & 0.20 & 0.40 & 0.49 & TH_PH & 0.47 & 0.54 & 0.60 \\
\hline TH_SG & 0.51 & 0.48 & 0.58 & TH_SG & 0.51 & 0.58 & 0.62 \\
\hline KR_CN & 0.08 & 0.04 & 0.03 & KR_CN & 0.19 & 0.27 & 0.37 \\
\hline KR_HK & 0.31 & 0.09 & 0.00 & KR_HK & 0.56 & 0.67 & 0.76 \\
\hline KR_TW & 0.44 & 0.35 & 0.55 & KR_TW & 0.61 & 0.68 & 0.77 \\
\hline CN_ID & 0.02 & -0.01 & 0.06 & CN_ID & 0.21 & 0.38 & 0.36 \\
\hline CN_MY & 0.15 & 0.17 & 0.03 & CN_MY & 0.24 & 0.41 & 0.40 \\
\hline CN_PH & 0.07 & 0.09 & 0.04 & CN_PH & 0.15 & 0.32 & 0.38 \\
\hline CN_SG & 0.16 & 0.21 & 0.21 & CN_SG & 0.23 & 0.35 & 0.42 \\
\hline CN_TH & 0.14 & 0.20 & 0.18 & CN_TH & 0.26 & 0.20 & 0.33 \\
\hline HK_ID & 0.15 & 0.00 & 0.05 & HK_ID & 0.44 & 0.68 & 0.66 \\
\hline TW_PH & 0.22 & 0.21 & 0.46 & TW_PH & 0.40 & 0.55 & 0.60 \\
\hline TW_SG & 0.51 & 0.44 & 0.56 & TW_SG & 0.56 & 0.69 & 0.77 \\
\hline TW_TH & 0.49 & 0.27 & 0.38 & TW_TH & 0.44 & 0.56 & 0.54 \\
\hline KR_ID & 0.22 & 0.34 & 0.55 & KR_ID & 0.47 & 0.60 & 0.66 \\
\hline KR_MY & 0.27 & 0.45 & 0.69 & KR_MY & 0.42 & 0.59 & 0.75 \\
\hline KR_PH & 0.19 & 0.34 & 0.60 & KR_PH & 0.41 & 0.58 & 0.66 \\
\hline KR_SG & 0.52 & 0.45 & 0.60 & KR_SG & 0.60 & 0.70 & 0.82 \\
\hline KR_TH & 0.46 & 0.31 & 0.43 & KR_TH & 0.49 & 0.58 & 0.58 \\
\hline WGBI_ID & 0.16 & 0.07 & 0.29 & MSCI_ID & 0.43 & 0.64 & 0.63 \\
\hline WGBI_MY & 0.25 & 0.30 & 0.36 & MSCI_MY & 0.39 & 0.63 & 0.67 \\
\hline WGBI_PH & 0.13 & 0.11 & 0.24 & MSCl_PH & 0.41 & 0.66 & 0.62 \\
\hline WGBI_SG & 0.71 & 0.65 & 0.66 & MSCI_SG & 0.63 & 0.79 & 0.81 \\
\hline WGBI_TH & 0.55 & 0.41 & 0.43 & MSCl_TH & 0.43 & 0.58 & 0.54 \\
\hline WGBI_CN & 0.13 & 0.23 & 0.25 & MSCl_CN & 0.19 & 0.28 & 0.42 \\
\hline WGBI_HK & 0.60 & 0.56 & 0.51 & MSCI_HK & 0.66 & 0.73 & 0.77 \\
\hline WGBI_TW & 0.45 & 0.42 & 0.42 & MSCl_TW & 0.59 & 0.63 & 0.736 \\
\hline WGBI_KR & 0.51 & 0.29 & 0.25 & MSCI_KR & 0.63 & 0.70 & 0.78 \\
\hline
\end{tabular}

Note: IN; Indonesia, MY; Malaysia, PH; the Philippines, SG; Singapore, TH; Thailand, CN; China, HK; Hong Kong, TW; Taiwan, KR; Korea; WGBI; Citigroup World Government Bond Index, MSCl; Morgan Stanley Capital International World Index. 
Table 2: Portfolio Investment in Asia



Note: 1 . The data are for 2010.

2. G20 developed economies include Australia, Canada, France, Germany, Italy, Japan, United Kingdom, and United States

3. G20 non-Asia emerging economies include Argentina, Brazil, India, Mexico, Russia, Saudi Arabia, South Africa, and Turkey.

Source: International Monetary Fund, Coordinated Portfolio Investment Surveyand World Economic Outlook Database (October 2012).

trend. A notable exception is China, whose degree of global and regional market integration remains low. By comparison, Asia's bond markets are less globally and regionally integrated except for those in Singapore and Hong Kong. Although there has been a notable increase in the intra-regional correlations of bond returns in the ASEAN region, the degree of intra-Asian integration generally remains lower in bond markets than it is in equity markets. Overall, Asia's bond markets are still divided by national borders and lagging behind equity markets in terms of cross-border integration.

\section{BARRIERS TO CROSS-BORDER INVESTMENT}

The above finding of closer market integration in equities than in bonds is consistent with the observation that the level of cross-border investment is higher in equities than it is in bonds in Asia. Table 2 shows the level of cross-border portfolio investment relative to GDP. Even in comparison with the average of advanced economies, the level of inward equity investment is relatively high in Korea and Malaysia as well as in Hong Kong and Singapore. By contrast, the level of cross-border bond investment is generally much lower in Asia than the average of advanced economies. Since the Asian crisis, Asian policy-makers have actively promoted the development of domestic bond markets in an attempt to diversify the sources of funding and reduce the concentration of credit, foreign exchange, and maturity risks in domestic banks. At national levels, the reform of securities market regulations and the improvement of market infrastructures were undertaken ${ }^{8}$. At regional levels, ASEAN+3 (China, Japan, Korea) finance ministers launched the Asian Bond Market Initiatives (ABMI) to address the common issues for the development of bond markets in the region ${ }^{9}$. Furthermore, the Asian Bond Funds (ABFs) were established by the EMEAP (Executive's Meeting of East Asia and Pacific Central Banks) to boost demand for Asian local bonds ${ }^{10}$. Despite these multilayered efforts, Asia's bond markets are lagging behind equity markets in terms of crossborder integrations. Although we cannot say for certain about the underlying causes, we speculate that crossborder bond investment can be facilitated by removing the barriers. In particular, the following four potential barriers to cross-border bond investment require policy responses at the national and regional levels.

First, bond markets in Asia are underdeveloped in terms of market size and liquidity. Although they have grown rapidly over the past decade, total bonds

\footnotetext{
${ }^{8}$ Some of major examples include China's launch of electronic trading platforms, Indonesia's creation of bond-pricing agency, and Thailand's revision of Securities Law. See Goswami and Sharma (2011) for more details.

${ }^{9}$ The major achievements of the ABMI include: (i) the launch of Asian Bonds Online (the website for information on Asian bond markets), (ii) the creation of Credit Guarantee and Investment Facility (CGIF: a trust fund providing credit guarantee for local currency denominated bonds issued by investment-graded companies in the region), and (iii) the establishment of ASEAN+3 Bond Market Forum (a common platform to foster standardization of market practices and harmonization of regulations related to cross-border transactions).

${ }^{10}$ The EMEAP is a cooperative organization of central banks and monetary authorities in the East Asia and Pacific region. The ABFs invest in sovereign and quasi-sovereign bonds issued in the EMEAP economies.
} 
outstanding remain relatively small in most Asian economies. The lack of liquidity in local markets could also be a serious obstacle to cross-border investment. Overall, Asia's bond markets, particularly corporate bond markets, are much less liquid than bond markets in advanced economies. Investors can be discouraged from investing in illiquid bond markets in which price discovery is not functioning well and price volatility tends to be great. Market liquidity can be improved by expanding investor base, improving market infrastructures, such as market making systems, trading platforms, and payment and settlement systems, and enhancing market transparency (Goswami \&Sharma, 2011).

Second, legal risks exist in cross-border bond investment because of the lack of information on the various regulatory frameworks across Asia. Therefore, it is important for policymakers to increase transparency by improving access to local information on laws and regulations as well as on market practices and to promote harmonization in key regulations and practices through regional financial cooperation.

The third potential barrier is the presence of greater foreign exchange uncertainty. As discussed earlier, exchange rate flexibility has increased substantially in many Asian economies since the Asian crisis. By contrast, derivatives markets such as foreign exchange futures, swaps, and options remain underdeveloped and most Asian economies lack instruments that can effectively hedge foreign exchange risk. In addition, the majority of Asian economies maintain varying degrees of control over the international use of domestic currencies in order to prevent harmful speculative attacks. Such controls include those on residents' issuance of domestic currency-denominated securities abroad and non-residents' issuance of domestic currency-denominated securities. The development of derivatives markets and internationalization of domestic currencies are thus necessary to encourage crossborder bond investment.

Finally, the presence of relatively stringent capital controls can be a serious barrier. Although capital controls can be useful in certain circumstances, such as following a rapid increase in capital inflows (Ostry et al., 2011), the empirical evidence indicates that they can adversely affect the development of financial systems in the long run (Chinn \& Ito, 2002). Table 3 shows the index of capital controls on portfolio investment in major Asian economies constructed by Schindler (2009) based on information provided in the
IMF's Annual Report Exchange Rate Arrangements and Restrictions. Overall, capital controls are relatively stringent in Asian economies, except in Hong Kong, Korea, and Singapore; indeed, some controls were tightened after the Asian crisis such as those in Indonesia, the Philippines, and Thailand. Nevertheless, the removal of excessive capital controls could serve as a driving force for greater cross-border bond investment and further market integration across Asia.

Table 3: Capital Control Index on Portfolio Investment

\begin{tabular}{|c|c|c|c|}
\hline & Year & Inflows & Outflows \\
\hline \multirow{3}{*}{ China } & 1997 & 1.0 & 1.0 \\
\hline & 2000 & 1.0 & 1.0 \\
\hline & 2005 & 1.0 & 1.0 \\
\hline \multirow{3}{*}{ Hong Kong } & 1997 & 0.0 & 0.0 \\
\hline & 2000 & 0.0 & 0.0 \\
\hline & 2005 & 0.0 & 0.0 \\
\hline \multirow{3}{*}{ Indonesia } & 1997 & 0.3 & 0.3 \\
\hline & 2000 & 0.5 & 0.5 \\
\hline & 2005 & 0.5 & 0.5 \\
\hline \multirow{3}{*}{ Korea } & 1997 & 0.8 & 0.3 \\
\hline & 2000 & 0.0 & 0.5 \\
\hline & 2005 & 0.0 & 0.3 \\
\hline \multirow{3}{*}{ Malaysia } & 1997 & 0.5 & 1.0 \\
\hline & 2000 & 0.5 & 1.0 \\
\hline & 2005 & 0.5 & 1.0 \\
\hline \multirow{3}{*}{ Philippines } & 1997 & 0.5 & 1.0 \\
\hline & 2000 & 0.5 & 1.0 \\
\hline & 2005 & 1.0 & 1.0 \\
\hline \multirow{3}{*}{ Singapore } & 1997 & 0.0 & 0.3 \\
\hline & 2000 & 0.0 & 0.5 \\
\hline & 2005 & 0.0 & 0.5 \\
\hline \multirow{3}{*}{ Thailand } & 1997 & 0.8 & 1.0 \\
\hline & 2000 & 0.5 & 0.8 \\
\hline & 2005 & 0.8 & 1.0 \\
\hline \multirow{3}{*}{$\begin{array}{l}\text { G20 (Developed } \\
\text { economies) }\end{array}$} & 1997 & 0.2 & 0.2 \\
\hline & 2000 & 0.1 & 0.1 \\
\hline & 2005 & 0.1 & 0.1 \\
\hline \multirow{3}{*}{$\begin{array}{c}\text { G20 (Non-Asia emerging } \\
\text { economies) }\end{array}$} & 1997 & 0.4 & 0.7 \\
\hline & 2000 & 0.4 & 0.6 \\
\hline & 2005 & 0.5 & 0.8 \\
\hline
\end{tabular}

Note: 1 . The index is the average of the indices for equity and bond investment controls.

2. G20 developed economies include Australia, Canada, France, Germany, Italy, Japan, United Kingdom, and United States.

3. G20 non-Asia emerging economies include Argentina, Brazil, India, Mexico, Russia, Saudi Arabia, South Africa, and Turkey.

Source: Schindler (2009). 
However, greater financial openness may expose domestic financial markets to the risk of contagion from abroad. Emerging market economies have responded to the instability associated with a surge in capital inflows by introducing macro-prudential controls (Ostry et al., 2011). Nonetheless, there remains a danger that the unilateral imposition of such controls in one country might accelerate capital inflows into other countries in the same region, placing undue upward pressure on their exchange rates. To avoid this, it is desirable for Asian countries to develop a region-wide guideline for capital controls under a regional cooperation framework, such as the ASEAN+3. Such guidance might help avoid the adverse impact of unilateral actions by outlining the prerequisites and procedures for the imposition of capital controls.

\section{CONCLUSION}

This study evaluates the time-varying degree of flexibility in exchange rate regimes and assesses the extent to which securities markets are integrated in East Asia. The DCC model developed by Engle (2002) is used to analyze the time-varying characteristics of the conditional correlations of exchange rates as well as of bond and equity returns among emerging Asian economies.

The empirical analyses of the correlations of exchange rates indicate that the degree of flexibility in Asia's exchange rate regimes has increased substantially since the exit from dollar pegs in the wake of the Asian crisis. Post-crisis exchange rate regimes can be best characterized as managed floating rates that have varying degrees of flexibility. A notable exception is China in which the renminbi continues to be managed with tight reference to the dollar even after the introduction of new regimes in 2005.

As the proposition of the Impossible Trinity suggests, fixed exchange rates and an autonomous monetary policy cannot coexist under free capital movement. Greater exchange rate flexibility allows Asian economies to relax capital controls further and promote financial integration without seriously undermining their willingness to adopt proactive macroeconomic policies. Intra-regional financial transactions, particularly portfolio investment, have resulted in less regional integration than have foreign trade and FDI. However, the promotion of financial integration through portfolio investment has distinct advantages, notably improving the efficiency and stability of financial markets in Asia.
The empirical analyses of the conditional correlations of equity returns indicate that Asia's equity markets are increasingly integrated both regionally and with the global market. A notable exception is China in which the degree of global and regional market integration remains relatively low. By comparison, Asia's bond markets are less globally and regionally integrated except for those in Singapore and Hong Kong. Although there has been a notable increase in the intra-regional correlations of bond returns in the ASEAN region, the degree of intra-Asian integration remains generally lower in bond markets than it is in equity markets. Overall, Asia's bond markets are still divided by national borders and lagging behind equity markets in terms of cross-border integration.

Although we cannot say for certain why Asia's bond markets are less integrated across borders, we speculate that cross-border bond investment can be facilitated by removing the potential barriers. These barriers include the lack of liquidity in local markets, legal risks due to lacking information on regulatory frameworks, greater foreign exchange uncertainty because of underdeveloped derivatives markets and the non-internationalization of domestic currencies, and the presence of relatively stringent capital controls in Asian economies. Serious efforts should be made at both national and regional levels to reduce these barriers in order to integrate the securities market through increased levels of cross-border investment.

Our findings indicate that there are more opportunities for emerging Asian economies to benefit from greater cross-border financial integration. By getting policy priorities right, these economies can foster more open and efficient financial systems that will contribute to sustainable growth and circumvent the pitfall of middle-income trap.

\section{APPENDIX A}

The DCC model used for the estimation consists of the following equations:

$$
\begin{aligned}
& E\left(\mathbf{r}_{t} \mid \Omega_{t-1}\right)=\mu_{t-1} \\
& \Sigma_{t-1}=\operatorname{Cov}\left(\mathbf{r}_{t-1} \mid \Omega_{t-1}\right)=\mathbf{D}_{t-1} \mathbf{R}_{t-1} \mathbf{D}_{t-1}
\end{aligned}
$$

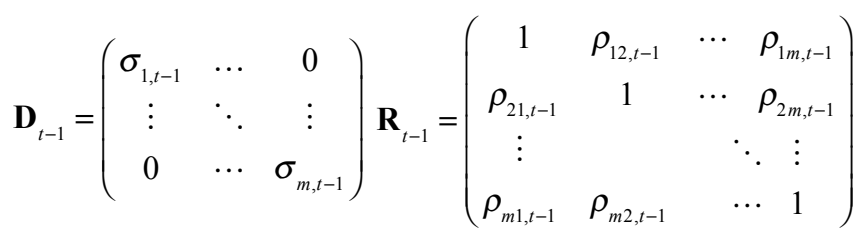




$$
\sigma_{i, t-1}^{2}\left(\lambda_{i}\right)=\lambda_{i} \sigma_{i, t-2}^{2}+\left(1-\lambda_{i}\right) r_{i, t-1}^{2}, i=1, \ldots m
$$

$$
\tilde{\rho}_{i j, t-1}(\delta)=\frac{q_{i j, t-1}}{\sqrt{q_{i, t,-1} q_{j j, t-1}}}, i \neq j=1, \ldots, m
$$

where $q_{i j, t-1}$ is given by

$q_{i j, t-1}=\bar{\rho}_{i j}\left(1-\delta_{1}-\delta_{2}\right)+\delta_{1} q_{i j, t-2}+\delta_{2} \tilde{r}_{i, t-1} \tilde{r}_{j, t-1}$

$$
\tilde{r}_{i t}=\frac{r_{i t}}{\tilde{\sigma}_{i t}^{2}(p)}
$$

where $\tilde{\sigma}_{i t}^{2}$ is given by

$\tilde{\sigma}_{i t}^{2}(p)=\frac{\sum_{s=0}^{p-1} r_{i, t-1}^{2}}{p}$

where $\mathbf{r}_{t}=\left(r_{1 t} \cdots r_{m t}\right)$ is an $m \times 1$ vector of asset returns that is assumed to follow the Student's $t$-distribution, $\Omega_{t-1}$ is the information set available at day $t-1, \mu_{t-1}$ is the mean returns, $\Sigma_{t-1}$ is the conditional covariance matrix of $\mathbf{r}_{t}, \mathbf{D}_{t-1}$ is a diagonal matrix with elements $\sigma_{i, t-1}$ denoting the conditional volatility of asset returns, $\mathbf{R}_{t-1}$ is the symmetric matrix with elements $\rho_{i j, t-1}$ denoting the conditional pairwise returns correlations between the $i^{\text {th }}$ and the $j^{\text {th }}$ assets, $\lambda_{i}$ is a parameter, $\tilde{\rho}_{i j, t-1}$ is the estimated conditional correlation, $\bar{\rho}_{i j}$ is the unconditional correlation, $\delta_{1}$ and $\delta_{2}$ are parameters, and $\tilde{r}_{i, t-1}$ and $\tilde{r}_{j, t-1}$ are standardized returns. For more details on the DCC model, see Engle (2002) and Pesaran and Pesaran (2009).

\section{ACKNOWLEDGEMENTS}

The authors are very grateful to the editors and three anonymous referees for their helpful comments on the earlier version of the paper. The research of the second author is in part supported by a Grant-in-Aid of the Japan Society for the Promotion of Science.

\section{REFERENCES}

Chinn, M. D.,\& Ito, H. (2002). Capital account liberalization, institutions and financial development: cross country evidence. NBER Working Paper No. 8967, National Bureau of Economic Research, Cambridge, MA.

Engle, R.F. (2002). Dynamic conditional correlation - a simple class of multivariate GARCH models. Journal of Business \& Economic Statistics, 20(3), 339-350. http://dx.doi.org/10.1198/073500102288618487
Felman, J., Gray, S., Goswami, M., Jobst, A., Pradhan, M., Peiris, S., \& Senevirante, D. (2011). ASEAN5 bond market development: where does it stand? Where is it going? IMF Working Paper WP11/137, International Monetary Fund, Washington DC.

Frankel, J., (1999). No Single Currency Regime is Right for All Countries or at All Times, NBER Working Paper No. 7338, National Bureau of Economic Research, Cambridge, MA

Fung, L.K., Tam, C., \& Yu, I. (2008). Assessing the integration of Asia's equity and bond markets. Bank for International Settlements Paper No. 42, Basel, pp. 1-37.

Furman, J., \& Stiglitz, J. E. (1998). Economic crises: Evidence and insights from East Asia. Brookings Papers on Economic Activity, 2, 1-114. http://dx.doi.org/10.2307/2534693

Goswami, M., \& Sharma, S. (2011). The development of local debt markets in Asia: An assessment. In M. Kawai \& E. S. Prasad (Eds.), Asian perspectives on financial sector reforms and regulation(pp. 223-252), Tokyo and Washington DC: Asian Development Bank Institute and Brookings Institution Press.

HSBC (2012). Factsheet: Asian local bond index (ALBI), HSBC Global Research, Fixed Income Asia (19 November) <http://www.hsbcnet.com/gbm/ attachments /asianindices/asian-local- bond-index- factsheet.pdf>.

Kinkyo, T. (2012). De facto exchange rate regimes in post-crisis Asia Economics Bulletin, 32, 2155-2165.

Ostry, J.D., Ghosh, A. R., Habermeier, K., Laeven, L., Chamon, M., Qureshi, M.S., \& Kokenyne, A. (2011). Managing capital inflows: What tools to use? IMF Staff Discussion Note, SDN/11/06, International Monetary Fund, Washington DC.

Pesaran, B., \& Pesaran, M.H. (2009).Time series econometrics using Microfit 5.0. Oxford University Press: Oxford.

Pongsaparn, R., \& Unteroberdoerster, O. (2011). Financial integration and rebalancing in Asia. IMF Working Paper WP/11/243, International Monetary Fund, Washington DC.

Prasad, E.S., \& Rajan, R.G. (2008). A pragmatic approach to capital account liberalization. Journal of Economic Perspectives, 22(3), 149-172. http://dx.doi.org/10.1257/jep.22.3.149

Savva, C.S., Osborn, D.R., \& Gill, L. (2009). Spillovers and correlations between US and major European stock markets: The role of the euro. Applied Financial Economics, 19(19), 1595-1604. http://dx.doi.org/10.1080/09603100802599563

Schindler, M. (2009). Measuring financial integration: A new data set. IMF Staff Papers, 56, 222-238. http://dx.doi.org/10.1057/imfsp.2008.28

Tamakoshi, G., \& Hamori, S. (2013). An asymmetric DCC analysis of correlations among bank CDS indices. Applied Financial Economics, 23(6), 475-481. http://dx.doi.org/10.1080/09603107.2012.727973

Toyoshima, Y., Tamakoshi, G., \& Hamori, S. (2012). Asymmetric dynamics in correlations of treasury and swap markets: Evidence from the US market. Journal of International Financial Markets, Institutions \& Money, 22(2), 381-394. http://dx.doi.org/10.1016/j.intfin.2011.12.002

Toyoshima, Y., Nakajima, T., and Hamori, S., (2013) Crude oil hedging strategy: New evidence from the data of the financial crisis, Applied Financial Economics, Vol. 23, No. 12, 1033 1041.

http://dx.doi.org/10.1080/09603107.2013.788779

Toyoshima, Y., \& Hamori, S. (2013). Asymmetric dynamics in stock market correlations: Evidence from Japan and Singapore. Journal of Asian Economics, 24, 117-123. http://dx.doi.org/10.1016/j.asieco.2012.08.001 
Xu, H., \& Hamori, S. (2012). Dynamic linkages of stock prices between the BRICs and the United States: Effects of the 2008-09 financial crisis. Journal of Asian Economics, 23, 344-352.

http://dx.doi.org/10.1016/j.asieco.2012.04.002
Yang, S-Y. (2005). A DCC analysis of international stock market correlations: The role of Japan on the Asian Four Tigers. Applied Financial Economics Letters, 1(2), 89-93. http://dx.doi.org/10.1080/17446540500054250

Received on 14-07-2014

Accepted on 04-08-2014

Published on 19-08-2014

DOI: http://dx.doi.org/10.6000/1929-7092.2014.03.22

(c) 2014 Kinkyo and Hamori; Licensee Lifescience Global.

This is an open access article licensed under the terms of the Creative Commons Attribution Non-Commercial License (http://creativecommons.org/licenses/by-nc/3.0/) which permits unrestricted, non-commercial use, distribution and reproduction in any medium, provided the work is properly cited. 